\title{
PENGARUH SISTEM OLAH TANAH DAN PEMBERIAN MULSA BAGAS TERHADAP POPULASI DAN BIOMASSA CACING TANAH PADA LAHAN PERTANAMAN TEBU TAHUN KE-5
}

\author{
Mufli Hatus Salamah, Ainin Niswati, Dermiyati \& Sri Yusnaini \\ Jurusan Agroteknologi, Fakultas Pertanian Universitas Lampung \\ Jl. Prof. Soemantri Brodjonegoro, No.1 Bandar Lampung 35145 \\ E-mail: mufli.hatussalamah34@gmail.com
}

\begin{abstract}
ABSTRAK
Penelitian ini bertujuan untuk mempelajari pengaruh sistem olah tanah dan aplikasi mulsa bagas terhadap populasi dan biomassa cacing tanah pada lahan pertanaman tebu tahun Ke-5. Penelitian ini dilaksanakan pada bulan Januari - Oktober 2015, di lahan pertanaman tebu PT GMP dengan perlakuan sistem olah tanah dan aplikasi mulsa bagas. Analisis cacing tanah dilakukan di Laboratorium Biologi Ilmu Tanah dan analisis contoh tanah dilakukan di Laboratorium Ilmu Tanah, Fakultas Pertanian, Universitas Lampung. Penelitian disusun secara split plot dalam rancangan acak kelompok terdiri dari 4 perlakuan dengan 5 ulangan atau 20 satuan percobaan. Data yang diperoleh dianalisis dengan sidik ragam yang sebelumnya telah diuji homogenitas ragamnya dengan Uji Bartlett dan aditivitasnya dengan Uji Tukey. Rata-rata nilai tengah diuji dengan uji BNT pada taraf 5\%. Untuk mengetahui hubungan antara populasi dan biomassa cacing tanah dengan C-organik, $\mathrm{pH}, \mathrm{kadar}$ air, dan suhu tanah dilakukan uji korelasi. Cacing tanah diamati dengan metode hand sorting dengan membuat monolith dengan ukuran $50 \mathrm{~cm}$ x $50 \mathrm{~cm}$ sedalam $30 \mathrm{~cm}$ dengan cara digali. Hasil penelitian pada pertanaman tebu tahun ke-5 menunjukan bahwa perlakuan tanpa olah tanah populasi cacing tanah pada pengamatan 9 BST dan biomassa cacing tanah pada pengamatan 3 BST lebih tinggi dibandingkan dengan perlakuan olah tanah intensif pada lahan pertanaman tebu tahun ke-5, sedangkan pemberian mulsa bagas populasi cacing tanah lebih tinggi dibandingkan dengan tanpa mulsa bagas pada pengamatan 3 BST. Tidak terdapat interaksi antara sistem olah tanah dan aplikasi mulsa bagas terhadap populasi dan biomassa cacing tanah. Terdapat 2 famili cacing tanah yang didapat yaitu famili Lumbricidae dan Glossoscolecidae.
\end{abstract}

Kata Kunci: cacing tanah, mulsa bagas, pengolahan tanah, tanpa olah tanah

\section{PENDAHULUAN}

Tebu (Saccharum officinarum L.) merupakan tanaman perkebunan yang penting karena sebagai bahan baku produksi gula. Produksi gula harus selalu ditingkatkan seiring dengan meningkatnya kebutuhan masyarakat akan gula. Beberapa upaya yang dapat dilakukan untuk meningkatkan produksi gula antara lain dengan perluasan areal tanam dan intensifikasi lahan yang ada. Intensifikasi lahan terus menerus menyebabkan tanah menjadi tidak produktif. PT GMP (2009) menyatakan bahwa pada saat ini telah terjadi penurunan hasil tebu setelah tanah digunakan sejak tahun 1975.

Salah satu upaya yang dapat dilakukan untuk memulihkan tanah terdegradasi tersebut adalah dengan kembali menerapkan sistem tanpa olah tanah (TOT) dan penambahan mulsa organik. Penerapan TOT dimaksudkan agar tanah kembali pulih keadaannya seperti pada saat lahan baru dibuka untuk pertanaman tebu. Di samping itu pemberian mulsa organik dimaksudkan untuk meningkatkan kandungan bahan organik di lahan tebu yang sudah menurun. Sebagai konsep daur ulang, mulsa organik yang dapat digunakan di perkebunan tebu adalah bagas (sisa perasan batang tebu untuk dijadikan gula). Masalahnya sampai berapa lama lahan terdegradasi tersebut untuk kembali menjadi subur.

Indikator kesuburan tanah dapat dilihat dari sifat kimia, fisik, dan biologi tanah. Salah satu sifat biologi tanah yang dapat dijadikan indikator kesuburan tanah adalah populasi dan biomassa cacing tanah. Cacing tanah sangat mempengarui proses dekomposisi, pedologi, serta siklus unsur hara dalam tanah. Pola penggunaan lahan yang intensif mempunyai pengaruh terhadap populasi dan biomassa cacing tanah. Tetapi sebaliknya cacing tanah mempunyai peranan penting terhadap perbaikan sifat fisik tanah yaitu menghancurkan bahan organik dan mencampuradukannya dengan tanah, sehingga terbentuk agregat tanah dan memperbaiki struktur tanah. Cacing tanah juga memperbaiki aerasi tanah melalui aktivitas pembuatan lubang dan juga 
memperbaiki porositas tanah akibat perbaikan struktur tanah. Selain itu cacing tanah mampu memperbaiki ketersediaan hara dan kesuburan tanah secara umum (Edward, 1998).

Aktivitas cacing tanah berubah-ubah tergantung dari kondisi lingkungannya, kondisi lingkungan tersebut antara lain: perubahan penggunaan lahan dan musim (hujan dan kemarau). Selain itu aktivitas cacing tanah menghasilkan kotoran (kascing). Menurut Sudharto dan Suwardjo (1989), aktivitas cacing tanah ditandai dengan adanya sisa kotoran cacing di permukaan tanah. Anas (1990), menyatakan bahwa kascing cacing lebih kaya akan C-organik, N-organik, P-tersedia, Ca dan Mg dapat dipertukarkan, serta kapasitas tukar kation (KTK) dan kejenuhan basa (KB).

Keberadaan cacing tanah juga merupakan salah satu indikator untuk menentukan tingkat kesuburan tanah di suatu lahan. Meskipun hewan tanah ini relatif kecil, kemampuannya untuk menggemburkan tanah dapat mencapai 40 kali lipat berat badannya. Soepardi (1983) menyatakan bahwa kualitas tanah tercermin dari aktivitas, diversitas, dan populasi mikro flora dan fauna tanah, seperti cacing tanah. Kombinasi sistem tanpa olah tanah dan pemberian mulsa diharapkan dapat memperbaiki kualitas tanah yang dapat diindikasikan dengan keberadaan cacing tanah. Oleh karena itu, penelitian ini dilakukan untuk mengetahui apakah pemberian mulsa bagas dan sistem tanpa olah tanah akan memperbaiki kualitas tanah setelah tiga tahun diberi perlakuan tersebut.

Untuk itu dilakukan penelitian dengan tujuan untuk mengetahui pengaruh sistem olah tanah terhadap populasi dan biomassa cacing tanah pada lahan pertanaman tebu tahun ke-5, mengetahui pemberian mulsa bagas terhadap populasi dan biomassa cacing tanah pada lahan pertanaman tebu tahun ke-5, dan mengetahui interaksi antara pengaruh sistem olah tanah dan pemberian mulsa bagas terhadap populasi dan biomassa cacing tanah pada lahan pertanaman tebu tahun ke-5.

\section{BAHAN DAN METODE}

Penelitian ini dilakukan pada Januari sampai dengan Oktober 2015 pada lahan pertanaman tebu di PT. Gunung Madu Plantations, Lampung Tengah. Analisis cacing tanah dan contoh tanah dilakukan di Laboratorium Ilmu Tanah, Fakultas Pertanian, Universitas Lampung.

Penelitian ini disusun secara split plot dalam Rancangan Acak Kelompok (RAK) yang terdiri dari 4 perlakuan dengan 5 ulangan atau 20 satuan percobaan.
Perlakuan yang diterapkan terdiri dari 2 faktor yaitu sistem olah tanah (T) dan aplikasi mulsa bagas (M). Sistem olah tanah terdiri dari tanpa olah $\operatorname{tanah}\left(\mathrm{T}_{0}\right)$ dan olah tanah intensif $\left(\mathrm{T}_{1}\right)$. Sedangkan aplikasi mulsa bagas terdiri dari tanpa mulsa bagas $\left(\mathrm{M}_{0}\right)$ dan mulsa bagas 80 t ha ${ }^{-1}\left(M_{1}\right)$. Pelaksanaan penelitian dilakukan dengan 3 tahapan, yaitu pengolahan tanah, pengambilan sampel cacing tanah, dan analisis tanah.

\section{Pengolahan Lahan}

Penelitian dilakukan dengan penggunaan dua sistem olah tanah, yaitu tanpa olah tanah dan olah tanah intensif, serta aplikasi mulsa bagas. Pada petak tanpa olah tanah, tanah tidak diolah sama sekali, gulma yang tumbuh dikendalikan dengan cara memberikan sisa tanaman tebu berupa bagas yang digunakan sebagai mulsa sedangkan BBA diletakkan dipermukaan tanah. Pada petak olah tanah intensif, tanah diolah sesuai dengan sistem pengolahan tanah yang diterapkan di PT GMP yaitu sebanyak 3 kali pengolahan dengan pemberian mulsa bagas. Pada olah tanah intensif BBA dicampurkan kedalam tanah sebelum aplikasi mulsa bagas. Pada semua petak perlakuan, diaplikasikan BBA sebanyak $80 \mathrm{t} \mathrm{ha}^{-1}$. Seluruh plot percobaan diaplikasikan pupuk sesuai dengan dosis yang biasa diaplikasikan di PT GMP yaitu Urea $300 \mathrm{~kg} \mathrm{ha}^{-1,}$ TSP $200 \mathrm{~kg} \mathrm{ha}^{-1,}$ dan $\mathrm{KCl} 300 \mathrm{~kg}$ $\mathrm{ha}^{-1}$.

2. Pengambilan Sampel Cacing Tanah

Sampel cacing tanah diambil dari bagian tengah pada setiap petakan. Pengambilan cacing tanah diawali dengan membuat lubang dengan ukuran $50 \times 50 \mathrm{~cm}$ dengan kedalam $30 \mathrm{~cm}$ dengan cara digali. Lubang yang digali tadi dihitung jumlah cacing tanahnya dengan menggunakan metode perhitungan tangan (hand sorting), Selanjutnya lubang tadi disiram secara perlahan dengan larutan mustard. Setiap cacing tanah yang didapat dihitung lalu dimasukkan kedalam plastik yang berisi tanah dan diberi label sesuai perlakuan. Setelah itu, cacing tanah dicuci dengan air bersih, dihitung dan ditimbang biomassanya. Selanjutnya cacing tanah dimasukkan kedalam botol yang berisi alkohol $70 \%$ untuk diklasifikasi jenisnya.

\section{Analisis Tanah}

Analisis C-organik tanah dilakukan dengan menggunakan Metode Walkley and Black, kadar air tanah menggunakan Metode Gravimetri, Suhu tanah menggunakan alat Termometer Tanah, dan $\mathrm{pH}$ tanah menggunakan Metode Elektrometrik.

\section{HASIL DAN PEMBAHASAN}

Pada pengamatan 3 BST pemberian mulsa bagas berpengaruh nyata terhadap populasi cacing tanah, dan 
Tabel 1. Hasil pengamatan populasi dan biomassa cacing tanah pada pertanaman tebu akibat perlakuan sistem olah tanah dan mulsa bagas

\begin{tabular}{|c|c|c|c|c|c|c|}
\hline \multirow{3}{*}{ Perlakuan } & \multicolumn{3}{|c|}{ Populasi Cacing Tanah } & \multicolumn{3}{|c|}{ Biomassa Cacing Tanah } \\
\hline & $3 \mathrm{BST}$ & $6 \mathrm{BST}$ & $9 \mathrm{BST}$ & $3 \mathrm{BST}$ & $6 \mathrm{BST}$ & $9 \mathrm{BST}$ \\
\hline & \multicolumn{3}{|c|}{$\left(\right.$ ekor $\left.\mathrm{m}^{-2}\right)$} & \multicolumn{3}{|c|}{$\left(\mathrm{g} \mathrm{m}^{-2)}\right.$} \\
\hline $\mathrm{T}_{0} \mathrm{M}_{0}$ & $16,00 \pm 4,00$ & $25,60 \pm 27,22$ & $11,20 \pm 10,73$ & $0,92 \pm 0,50$ & $0,63 \pm 0,36$ & $0,33 \pm 0,28$ \\
\hline $\mathrm{T}_{0} \mathrm{M}_{1}$ & $36,80 \pm 15,07$ & $28,80 \pm 13,68$ & $20,00 \pm 8,94$ & $0,98 \pm 0,24$ & $0,72 \pm 0,24$ & $0,52 \pm 0,37$ \\
\hline $\mathrm{T}_{1} \mathrm{M}_{0}$ & $20,00 \pm 8,49$ & $3,20 \pm 3,35$ & $3,20 \pm 1,79$ & $0,73 \pm 0,16$ & $0,78 \pm 1,21$ & $0,37 \pm 0,56$ \\
\hline $\mathrm{T}_{1} \mathrm{M}_{1}$ & $24,80 \pm 16,35$ & $12,00 \pm 12,65$ & $4,00 \pm 4,90$ & $0,64 \pm 0,55$ & $0,60 \pm 0,59$ & $0,50 \pm 0,78$ \\
\hline Sumber Keragaman & \multicolumn{6}{|c|}{ Signifikansi } \\
\hline $\begin{array}{l}\text { Pengolahan } \\
\text { Tanah(T) }\end{array}$ & tn & tn & $*$ & $*$ & tn & tn \\
\hline $\begin{array}{l}\text { Pemberian } \\
\text { Mulsa(M) }\end{array}$ & $*$ & tn & tn & tn & tn & tn \\
\hline $\begin{array}{l}\text { Interaksi } \\
(\mathrm{T} \times \mathrm{M})\end{array}$ & tn & tn & tn & tn & tn & tn \\
\hline
\end{tabular}

Keterangan: $\mathrm{T}_{1}=$ olah tanah intensif $; \mathrm{T}_{0}=$ Tanpa Olah Tanah $; \mathrm{M}_{1}=$ Mulsa bagas $80 \mathrm{t} \mathrm{ha}^{-1} ; \mathrm{M}_{0}=$ tanpa mulsa; BST $=$ bulan setelah tanam; $*$ = berbeda nyata pada taraf $5 \% ;$ tn $=$ tidak berbeda nyata pada taraf $5 \%$

Tabel 2. Hasil uji BNT pengaruh pemberian mulsa bagas terhadap populasi cacing tanah pada tanaman tebu pada 3 BST

\begin{tabular}{cc}
\hline Perlakuan & $\begin{array}{c}\text { Populasi Cacing Tanah } \\
\left({\text { ekor } \mathrm{m}^{-2}}^{2}\right.\end{array}$ \\
\hline Tanpa mulsa & $8,00 \mathrm{a}$ \\
Dengan mulsa & $30,80 \mathrm{~b}$ \\
\hline BNT 0,05 & 11,28 \\
\hline
\end{tabular}

Keterangan: Angka yang diikuti oleh huruf yang sama tidak berbeda nyata dengan uji BNT pada taraf nyata $5 \%$

populasi cacing tanah lebih tinggi dibandingkan dengan tanpa mulsa bagas (Tabel 1 dan 2). Hal ini diduga perlakuan karena mulsa bagas memberikan bahan organik yang lebih banyak untuk cacing tanah, sehingga terdapat sumber energi yang menunjang untuk perkembangan populasi cacing tanah, karena bahan organik merupakan sumber energi bagi makro dan mikro-fauna tanah. Edward dan Arancon (2004) menyatakan bahwa di beberapa habitat, cacing tanah merupakan organisme utama penghancur bahan organik. Populasi cacing tanah biasanya akan meningkat dengan ketersediaan bahan organik. Selain itu pemberian mulsa berada pada permukaan tanah sehingga memberikan fungsi lebih baik bagi lingkungan tanah dan BBA yang dicampur secara merata di dalam tanah membuat pertumbuhan cacing tanah menjadi lebih optimal. Hal ini sesuai dengan penelitian Sibuea (2014) dan Helyanto (2015), yang menyimpulkan pengaplikasian mulsa bagas meningkatkan populasi dan biomassa cacing tanah pada pertanaman tebu.

Pemberian mulsa bagas memberikan sumber energi yang baik bagi cacing tanah. Ketersediaan sumber energi ini dapat menyebabkan perkembangan aktifitas cacing tanah menjadi lebih baik. Sebaliknya kandungan bahan organik yang kurang menyebabkan sumber energi yang terbatas untuk cacing tanah. Jika sumber energi terbatas tentunya aktifitas cacing tanah tidak cukup baik. Jadi penambahan mulsa di samping sebagai sumber hara bagi tanaman, sekaligus sebagai sumber energi dan hara bagi mikroba. Makin kaya kandungan bahan organik dalam tanah, makin banyak dihuni oleh organisme tanah yaitu cacing tanah.

Sedangkan pada pemberian mulsa bagas yang awalnya berpengaruh nyata tetapi selanjutnya tidak berbeda nyata terhadap biomassa cacing tanah hal ini diduga kandungan bahan organik pada lahan itu berkurang karena pada pengamatan 6 BST dan 9 BST lahan tidak diberi bahan organik yaitu mulsa bagas dan BBA, dimana bahan organik ini adalah sumber makanan bagi cacing tanah.

Menurut Tiara (2010), pemberian mulsa dapat memperbaiki sifat fisika, kimia, dan biologi tanah karena dengan pemberian mulsa dapat meningkatkan aktivitas 
organisme tanah sehingga merupakan salah satu komponen penting dalam meningkatkan pertumbuhan dan hasil tanaman.

Mulsa bagas belum berpengaruh terhadap biomassa cacing tanah karena kandungan $\mathrm{C} / \mathrm{N}$ rasio bagas yang tinggi ( $\mathrm{C} / \mathrm{N} 86)$, sehingga mulsa bagas belum terdekomposisi secara keseluruhan menjadi C-organik tanah dan unsur hara lainnya, karena waktu yang dibutuhkan untuk pembentukan C-organik tanah cukup lama. Menurut Catalan (1981), pertumbuhan dan laju produksi cacing tanah sangat bergantung pada jenis dan populasi pakan yang dikonsumsi.

Pelakuan tanpa pengolahan tanah meningkatkan populasi dan biomassa cacing tanah lebih tinggi dibandingkan dengan perlakuan olah tanah intensif (Tabel 1 dan 3). Hal ini diduga karena tanah tidak diolah dan sisa tanaman dibiarkan pada permukaan tanah sehingga cacing tanah yang berada di dalam tanah tidak terganggu dan populasinya akan meningkat. Perlakuan tanpa olah tanah memberikan ruang udara tanah yang lebih baik terhadap cacing tanah dibandingkan dengan perlakuan olah tanah intensif.

Perlakuan tanpa olah tanah memberikan aktivitas mikroba perombak tanah pada permukaan tanah yang lebih besar dibandingkan dengan pengolahan tanah intensif. Hal ini dikarenakan residu organik dari tanaman sebelumnya mengumpul pada permukaan tanah, sehingga aktivitas perombak tanah meningkat. Oleh karena itu TOT berpengaruh terhadap populasi dan biomassa cacing tanah. Penerapan olah tanah konservasi (OTK) yaitu dengan sistem tanpa olah tanah (TOT) dapat digunakan untuk memperbaiki kualitas tanah. TOT cenderung memiliki lebih banyak efek positif terhadap keanekaragaman beberapa biota tanah dibandingkan dengan pengolahan tanah. Utomo (2006), menambahkan bahwa penggunaan olah tanah konservasi jangka panjang ternyata dapat meningkatkan jumlah dan keanekaragaman biota, hal ini ditunjukkan dengan jumlah bakteri, mesofauna dan cacing tanah yang lebih tinggi dibandingkan dengan perlakuan sistem olah tanah intensif (OTI).

Perlakuan olah tanah tidak berpengaruh terhadap populasi cacing tanah pada awal pertanaman tebu yaitu 3 BST dan 6 BST, hal ini diduga karena sistem olah tanah mempengaruhi kehidupan cacing tanah. Perbedaan sistem olah tanah akan mempengaruhi tinggi rendahnya populasi cacing tanah, selain itu hal ini diduga karena pengaruh dari sistem olah tanah intensif yang telah diterapkan PT Gunung Madu selama ini, sehingga mempengaruhi kondisi tanah dan biota yang ada di dalam tanah, hal ini sejalan dengan penelitian Sibuea (2014), yang melakukan pengamatan tahun ke-4, dari hasil penelitian menunjukan belum adanya pengaruh dari

Tabel 3. Hasil uji BNT sistem olah tanah terhadap populasi dan biomassa cacing tanah pada tanaman tebu 3 BST

\begin{tabular}{ccccc}
\hline \multirow{2}{*}{ Perlakuan } & \multicolumn{2}{c}{9 BST } & \multicolumn{2}{c}{3 BST } \\
\cline { 2 - 5 } & Biomassa $\left(\mathrm{g} \mathrm{m}^{-2}\right)$ & Populasi $\left(\mathrm{ekor} \mathrm{m}^{-2}\right)$ & Populasi $\left(\mathrm{ekor} \mathrm{m}^{-2}\right)$ & Biomassa $\left(\mathrm{g} \mathrm{m}^{-2}\right)$ \\
\hline Olah Tanah Intensif & $0,43 \mathrm{a}$ & $3,60 \mathrm{a}$ & $23 \mathrm{a}$ & $0,69 \mathrm{a}$ \\
Tanpa Olah Tanah & $0,44 \mathrm{a}$ & $15,60 \mathrm{~b}$ & $27 \mathrm{a}$ & $0,95 \mathrm{~b}$ \\
\hline BNT 0,05 & & 5,82 & & 0,17 \\
\hline
\end{tabular}

Keterangan: Angka yang diikuti oleh huruf yang sama tidak berbeda nyata dengan uji BNT pada taraf nyata 5\%

Tabel 4. Pengaruh sistem olah tanah dan aplikasi mulsa bagas pada pertanaman tebu terhadap C-Organik, $\mathrm{pH}$ tanah, kadar air tanah, dan suhu tanah

\begin{tabular}{ccccccccc}
\hline \multirow{2}{*}{ Perlakuan } & C-Organik $(\%)$ & pH tanah & \multicolumn{3}{c}{ Kadar Air Tanah $(\%)$} & \multicolumn{3}{c}{ Suhu Tanah $\left({ }^{\circ} \mathrm{C}\right)$} \\
\cline { 2 - 9 } & 3 BST & 3 BST & 3 BST & 6 BST & 9 BST & 3 BST & 6 BST & 9 BST \\
\hline T0M0 & 1,45 & 5,32 & 22,74 & 24,04 & 23,70 & 30,40 & 27,40 & 26 \\
T0M1 & 1,34 & 5,34 & 22,30 & 25.03 & 25,03 & 30,40 & 27,80 & 26 \\
T1M0 & 1,28 & 5,27 & 18,41 & 21,74 & 20,32 & 30,20 & 27,20 & 25,60 \\
T1M1 & 1,22 & 5,23 & 20,51 & 22,61 & 21,31 & 30,40 & 27,20 & 25,80 \\
\hline
\end{tabular}

Keterangan : $\mathrm{T}_{1}=$ olah tanah; $\mathrm{T}_{0}=$ tanpa olah tanah; $\mathrm{M}_{1}=$ aplikasi mulsa bagas; $\mathrm{M}_{0}=$ tanpa aplikasi mulsa bagas 
Tabel 5. Uji korelasi antara sifat tanah dengan populasi (ekor $\mathrm{m}^{-2}$ ) dan biomassa cacing tanah (ekor $\left.\mathrm{m}^{-2}\right)$ pada lahan pertanaman tebu.

\begin{tabular}{|c|c|c|c|}
\hline \multirow{2}{*}{$\begin{array}{l}\text { Bulan setelah tanam } \\
\text { (BST) }\end{array}$} & \multirow{2}{*}{ Variabel } & \multicolumn{2}{|c|}{ Koefisien korelasi (r) } \\
\hline & & Populasi cacing tanah & Biomassa cacing tanah \\
\hline \multirow[t]{2}{*}{$3 \mathrm{BST}$} & C-Organik $^{1)}$ & $0,09^{\mathrm{tn}}$ & $0,16^{\mathrm{tn}}$ \\
\hline & $\mathrm{pH} \operatorname{tanah}^{1)}$ & $0,41^{\mathrm{tn}}$ & $0,07^{\mathrm{tn}}$ \\
\hline \multirow[t]{2}{*}{ 3, 6, dan 9 BST } & Suhu tanah ${ }^{2)}$ & $0,33^{*}$ & $0,27^{\mathrm{tn}}$ \\
\hline & Kadar air tanah ${ }^{2)}$ & $0,14^{\mathrm{tn}}$ & $0,08^{\mathrm{tn}}$ \\
\hline
\end{tabular}

Keterangan: ${ }^{\text {tn }}=$ tidak berpengaruh nyata $;{ }^{*}=$ berpengaruh nyata pada taraf $5 \% ;{ }^{1)}=\mathrm{n}=20 ;{ }^{2)}=\mathrm{n}=60$
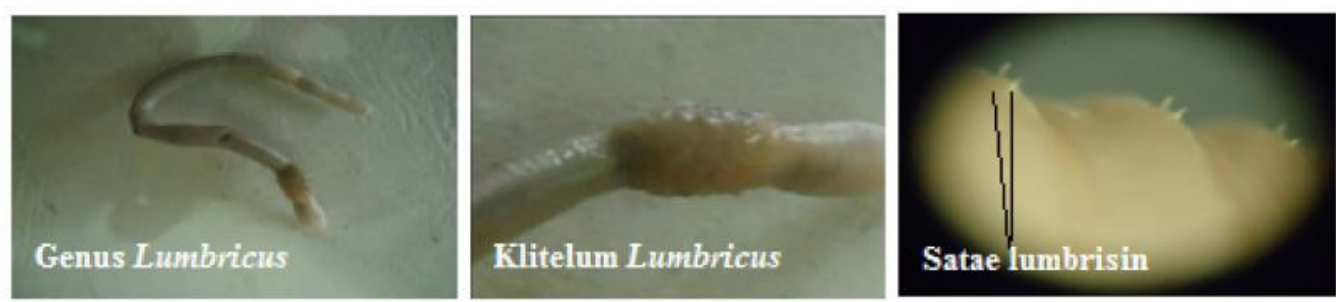

Gambar 1. Hasil identifikasi cacing tanah pada lahan pertanaman tebu, klitelum Lumbricus dan setae lumbrisin
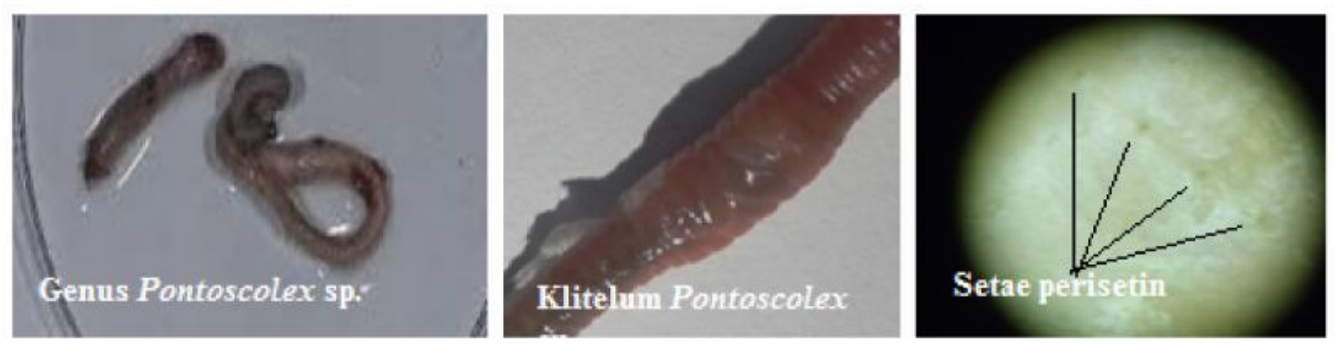

Gambar 2. Hasil identifikasi cacing tanah pada lahan pertanaman tebu, klitelum Pontoscolex sp. dan setae perisetin

sistem olah tanah terhadap populasi dan biomassa cacing tanah.

Pada pengamatan 9 BST, populasi cacing tanah meningkat 5 kali pada perlakuan tanpa olah tanah dibandingkan olah tanah intensif tetapi biomassa cacing tanah tidak nyata (Tabel 3). Hal ini dikarenakan cacing tanah yang didapatkan pada perlakuan tanpa olah tanah memiliki bobot yang kecil selain itu banyak telur cacing sehingga penilaian biomassa cacing tanah berbeda dengan hasil populasi cacing tanah. Hasil penelitian Sugiyarto (2003), menunjukkan bahwa semakin tinggi intensitas pengelolaan lahan menyebabkan biodiversitas makrofauna tanah semakin menurun. Penelitian lain menunjukkan bahwa berkurangnya populasi dan biomassa cacing tanah sering ditemukan pada pengolahan tanah intensif karena adanya perubahan lingkungan tanah yang tidak diinginkan sebagai dampak pengolahan tanah yang berlebihan (Chan, 2001).
Hasil uji korelasi populasi dan biomassa cacing tanah (Tabel 4 dan 5) menunjukkan bahwa pH tanah, kadar air tanah, dan C-organik tanah tidak berkolerasi dengan populasi dan biomassa cacing tanah, suhu tanah berkorelasi positif dengan populasi cacing tanah, namun tidak berkorelasi dengan biomassa cacing tanah. Suhu tanah merupakan salah satu faktor lingkungan yang berpengaruh terhadap produksi kokon dan reproduksi cacing tanah. Menurut Budiarti dan Palungkun (1992) menyatakan suhu yang diperlukan untuk pertumbuhan cacing tanah dan penetasan kokon adalah sekitar 15$25^{\circ} \mathrm{C}$. Bila suhu terlalu tinggi atau terlalu rendah maka semua proses fisiologis seperti pernafasan, pertumbuhan, perkembangbiakan, dan metabolisme akan terganggu. Suhu tanah akan menjadi lebih terjaga kestabilannya akibat terdapat naungan mulsa serasah tanaman yang melindungi tanah dari terpaan sinar langsung matahari. 
Berdasarkan hasil identifikasi cacing tanah, genus cacing tanah yang didapat dari petak percobaan adalah terdapat 2 genus dari 2 famili yaitu genus Lumbricus (Family Lumbricidae) dan genus Pontoscolex (family Glossoscolecidae) (Gambar 1 dan 2). Dilihat dari jenisnya hanya terdapat 2 genus cacing tanah yang berhasil diindetifikasi. Hal ini diduga karena PT GMP menerapkan sistem olah tanah intensif dalam pengolahan lahan perkebunannya yang telah berlangsung sejak lama. Sistem olah tanah intensif sendiri biasanya menggunakan pupuk kimia untuk mencukupi kebutuhan unsur hara tanaman dan penggunaan pestisida untuk mengendalikan gulma dan hama penyakit tanaman, sehingga bahan kimia yang digunakan tersebut lama-kelamaan akan berpengaruh terhadap kondisi tanahnya dan mempengaruhi kehidupan biota tanah, termasuk keanekaragaman cacing tanah. Hasil penelitian Sugiyarto (2003) menunjukan bahwa semakin tinggi intensitas pengelolaan lahan menyebabkan biodiversitas makrofauna tanah semakin menurun.

\section{KESIMPULAN}

Kesimpulan yang dapat ditarik dari penelitian ini adalah perlakuan tanpa olah tanah populasi cacing tanah pada pengamatan 9 BST dan biomassa cacing tanah pada pengamatan 3 BST lebih tinggi dibandingkan dengan perlakuan olah tanah intensif pada lahan pertanaman tebu tahun ke-5. Pemberian mulsa bagas populasi cacing tanah lebih tinggi dibandingkan dengan tanpa mulsa bagas pada pengamatan $3 \mathrm{BST}$ pada lahan pertanaman tebu tahun ke-5, tidak terdapat interaksi antara sistem olah tanah dan aplikasi mulsa bagas terhadap populasi dan biomassa cacing tanah, serta terdapat 2 famili cacing tanah yang didapat dari hasil identifikasi, yaitu famili Lumbricidae dan Glossoscolecidae.

\section{DAFTAR PUSTAKA}

Anas, I. 1990. Metode Penelitian Cacing Tanah dan Nematoda. Penuntun Praktikum DAU Bioteknologi. IPB. Bogor. $252 \mathrm{hlm}$.

Arancon, N.Q., C. A. Edwards, R. Atiyeh, dan J. D. Metzger. 2004. Effect of vermicompost produced from food waste on the growth and yields of greenhouse peppers. Bioresource Tecnology. 93: 139-144.

Catalan, G.I. 1981. Earthworms a New-Resource of Protein. Philippine Earthworms center. Philippines. $389 \mathrm{hlm}$.

Edward, C. A., 1998. Earthworm Ecology. St. Lucie Press. Washington, DC. $389 \mathrm{hlm}$.

Helyanto, J. 2015. Pengaruh sistem olah tanah dan pemberian mulsa bagas pada lahan tebu PT. GMP ratoon ke-3 terhadap populasi dan biomassa cacing tanah serta populasi dan keanekaragaman mesofauna tanah. Skripsi. Universitas Lampung. Bandar Lampung. 66 hlm.

Palungkun, R. danA. Budiarti. 1992. Cacing Tanah. Penebar Swadaya. Jakarta.

Sibuea, A. M. P. 2014. Pengaruh olah tanah dan aplikasi mulsa bagas terhadap populasi dan biomassa cacing tanah pada pertanaman tebu ratoon ke-2. Skripsi. Universitas Lampung. Bandar Lampung.

Soepardi, G. 1983. Sifat dan Ciri Tanah. IPB. Bogor. $519 \mathrm{hlm}$.

Sudharto, T. dan Suwardjo. 1989. Pengaruh pemberian macam bahan organik terhadap aktivitas cacing tanah (Perionyx sp.) dan hasil tanaman kedelai. Prosiding Pertemuan Teknis Penelitian Tanah. Pusat Penelitian Tanah Badan Penelitian dan Pengembangan Pertanian. Departemen Pertanian. Bogor. $15 \mathrm{hlm}$.

Sugiyarto. 2003. Konservasi Makrofauna Tanah dalam Sistem Agroforestri. Puslitbang Bioteknologi dan Biodiversitas LPPM UNS. Surakarta.

Tiara, D.M. 2010. Pemanfaatan Limbah Tebu: Perspektif PT. Gunung Madu Plantation. Available online at http://koranpdhi.com/buletinedisi8/edisi8-peternakan2.htm., [1 Oktober 2015].

PT. GMP. Pengolahan Tanah. Available online at www.gunungmadu.co.id., [12 Maret 2015].

Utomo, M. 2006. Bahan Buku Pengelolaan Lahan Kering Berkelanjutan. Universitas Lampung. Bandar Lampung. $25 \mathrm{hlm}$. 